\title{
Western Television Programmes and the African Cultural Identity of Nigerian Youths
}

\author{
Dr. Babaleye,Samuel Oloruntobi Taye \\ Associate Professor and Head, Communication and Media Studies Programme \\ Afe Babalola University, Ado-Ekiti (ABUAD), Nigeria \\ Ajisafe, Ibikunle Olayiwola, (MSc).,
}

Department of Communication and Media Studies, Afe Babalola University, Ado-Ekiti (ABUAD)

\begin{abstract}
There is a general trend of African cultural erosion among Nigerian youths. Majority of them do not take pride in anything Nigerian: fashion, food, language, music and literature. Their behavioral attitudes show poor African cultural orientation. This study therefore examined the impact of Western television programmes on the African cultural identity of Nigerian youths A quantitative survey research questionnaire was administered on 274 respondents drawn from Afe Babalola University and Ekiti State University to determine the impact of Western television programmes on the cultural values of Nigerian youths. Cultural Imperialism and Social Learning theories were applied to test a null hypothesis that Western television Programmes have no significant relationship on the cultural values of Nigerian Youths. Chi Square was used to test the hypothesis. Result showed that western television programmes have negative influence on the cultural values of Nigerian youths: $274 / 5<54.8$, at 05 level of significance. Findings revealed that majority of youths watch Western television programmes for fashion and entertainment. Respondents agreed that Western television programmes glamourize risky behaviours: alcoholism, drug abuse and sexual promiscuity. The study recommends the promotion of African cultural values on Nigerian television. The Nigerian Broadcasting Commission (NBC) should effectively censor foreign programmes on Nigerian TV channels.
\end{abstract}

Keywords: Cultural values, Western television programmes, norms and traditions, cultural imperialism, social learning theories, African cultural identity, television technology

\section{INTRODUCTION}

The importance of the mass media in the socio-political, cultural and economic development of the human society cannot be over-emphasized. In this $21^{\text {st }}$ Century the world depends largely on the media for news on every aspect of human endeavor. The mass media inform, entertain, sensitize, persuade, mobilize and educate people about happenings in their environment and in other faraway places for complete human development. Thus, the media are involved in the teaching of norms and values which may not all enhance good social development. In other words, there are positive and negative effects of the mass media on the human society. Globalization is often portrayed as a way to increase the diversity and the richness of culture by giving expression to the variety of information circulating in the media. The reality, however, is to the contrary as the global media tend to be dominated by Western Hollywood values, Western products, perspectives and culture. Without much argument, the English language is the main carrier of this Western hegemonic culture (Salawu, 2003). The way Nigerian youths speak English and abandon their mother tongue is embarrassing. Many of the youths cannot read and write in the Nigerian languages. They start the use of English right from kindergartens because their parents encourage them to speak English language. As they grow up they unfortunately fall for the Western cultures through watching foreign programmes on the television. The phenomenon has made majority of them to become aliens to the African cultural values. English language, as observed by Salawu (2006), is gradually but steadily eradicating the national Nigerian languages. Quoting Salawu (2006), Ayedun-Aluma and Adenle-Tijani (2014) believe that culture encompasses the entire gamut of a people's ways of life. Culture is reflected in the socio-politicaleconomic system of a people. And by far, culture is more predominantly reflected in a people's mode of communication. This of course refers to a language because language is the single most characteristic element of a people's culture, they add that any impairment or erosion of a people's 
language significantly signposts the death of that people's culture and, essentially the essence of their being.

Television popularly called 'Tee-Vee' is the most influential among media distribution channels. Television broadcasting is the transmission of visual images of moving and stationary objects, generally with accompanying sound, as electromagnetic waves and the reconversion of received waves into visual images. Ariyibi-Oke (2007) says it combines the use of light, colour, sound and motion. Rodman (2006) submits that: "Television remains the most time-consuming activity, next to sleeping and it is the world's main source of news and information. It is the medium through which politics is conducted, and it is humanity's main form of entertainment. It is also the world's most powerful sales tool."Television today has succeeded in combining the latest technology as an attraction to the 'youth' audience which has endeared them due to its interactivity. It is clear that the youths are at the forefront of technology revolution which remains the major driving force behind the global emergence and revolution of the information and knowledge based society. Technology has created the possibility and likelihood of global culture. The internet, satellite and cable T.V have swept away the so-called national cultural boundaries. For this simple reason, it has become very easy for people to get attracted to televised programmes and by so doing become addicted. According to Babaleye, (2012) the television has a captivating effect on viewers such that viewers, especially the youths would want to imitate their heroes on television by trying to do what such characters do on the television screen.

Television broadcasting began first in Britain in 1936, followed by United States of America in 1939. The first television station in Nigeria, was established by the Western Regional Government on $1^{\text {st }}$ October, 1959, a year before Nigeria's independence on $1^{\text {st }}$ October, 1960. Known as the Western Nigerian Television (WNTV), it was the first in Africa. The Eastern Nigerian Government followed suit in 1960 with the establishment of the Eastern Nigeria Television (ENTV), Enugu, as part of the attractions to mark the independence of Nigeria from the British rule in that part of the country. Ever since, the spread of television broadcasting has covered the whole country with many privately owned tv stations in addition to the government owned stations. Today, there are 450 active public and private television stations in Nigeria, whose programmes and contents cater for various tv viewers, old and young. These stations provide such shows as comedy, sports, cartoons, home videos, movies, soap operas, international shows and local political debates. Added to these television stations in Nigeria is Multi Choice popularly called DStv. Multi-Choice is a premium pay-as-you-watch television, connected to many homes in Nigeria through the DStv platform that has over two hundred channels. In addition, there are other satellite pay-per-view platforms such as MITV, DBN, CHANNELS, EMMANUEL TV, DOVE TV, AIT, Silver bird, GoTV and Star times and lately TVC News otherwise called Television Continental whose main objective is to cover news of Africa from African perspectives. All these TV stations have a variety of interesting programmes that hold viewers spellbound.

Technology can confidently be said to have brought a lot in terms of Western civilization and culture into Africa. Traditional African cultural practices have paved way for foreign ways of doing things. As argued by Mimiko (2010), the social fabric was completely devastated and a new culture of violence was implanted. For instance, traditional African system of conflict resolution was destroyed, the African democratic process was brutally uprooted and replaced by the authoritarian colonialism; a new crop of elites was created, nurtured, and weaned on the altar of violence and colonialism armed with structures of the modern state to replace the revered traditional African leadership institutions, while subjugating the masses to the service of western democratic principles. One could infer that when westernized values were imported to Africa, the hidden agenda of western modernism was based simply on materialistic interests.

\section{Statement of the Problem}

It is widely known that the media can teach norms and values by way of symbolic reward and punishment for different kinds of behaviours. Western television programmes and their impact on the cultural values of Nigerian youths have been observed to be a major problem. Many Nigerian youths tend to imitate Western cultures especially American and European cultures and values. The Nigerian youths appear to see everything Western in a positive light, and superior to that of African or Nigerian cultures, norms and values. This study therefore seeks to examine the effect of Western television programmes on the African cultural identity of Nigerian youths. 


\section{OBJECTIVES OF THE STUDY}

1. The main objective of this study is to find out how Western television programmes affect the African cultural values of Nigerian youths. Others include:

2. to assess the implications of these Western television programmes on the cultural values and African identity of Nigerian youths.

3. to determine which of the Western television programmes are beneficial to the youths in accordance to African cultures, norms and traditions.

4. to examine how television as a channel of mass communication can be used to promote African cultural values.

\section{RESEARCH HYPOTHESES}

$\mathrm{H}_{\mathbf{0}}$ : Western television programmes have no negative effect on the African cultural identity of Nigerian youths

\section{European Culture ANd Colonialism of AFrica}

The so-called civilization brought by the Europeans was just another concept of domination, imposition of a foreign culture over African traditional cultural values. It is important to emphasize fundamentally that urgent and more decisive steps need to be taken to reorder and reverse the fading trend of cultural emptiness, without which Africa may experience seasons of cultural extinction and drought of African values. Colonisation of the continent was destructive in terms of cultural heritage and values for which Africa was famous. Colonialism was precariously retrogressive as the continent was robbed of decades of opportunities- opportunities of self-development, opportunities of selfgovernment, and indeed, opportunities of self-styled technological development. The television is thus a powerful socializing agent because of its attributes to impose and stamp images permanently on the minds of its viewers, especially the youths. (SAlawu, 2003; Ayedun-Alum, Victor and Tijani-Adenle, Ganiyat, 2014),

\section{African Cultural Values}

The cultural values of any society is the commonly held standards of what is acceptable or unacceptable, important or unimportant, right or wrong, workable or unworkable in a community or society. http://www.businessdictionary.com. The culture of every nation is an important aspect of that nation and should be preserved (Nwaolikpe, 2013).Culture is the lifestyle of the people in a society and denotes their values, beliefs, artifacts and behaviour. It is the totality of the way of life of a people which is passed down from one generation to another. A culture exists when a distinct way of life shapes what a group of people believe, value and do (Wood, 2009). The African cultural values are distinct and vary from one region to the other and Nigeria being the largest African country, with over 200 tribes has the largest concentration of African cultures and civilizations. In fact, every Nigerian tribe has distinct cultural values which are evident in their language, music, songs, dance, marriage rites, greetings, mode of dressing and many more. However, according to Nwagbara and Umor (2012), the Nigerian culture is a complex subject that involves more than music and dancing or arts in general. It encompasses the material and nonmaterial aspects of culture. The material includes the food, clothing building architecture, fine arts and any other physical items, while the non-material includes African philosophy, religion and beliefs, language, proverbs and idioms, morals, behaviour, character, ethics and many other creative aspects. An American Sociologist, Charles Ellenwood describes Culture as the collective name for all behavioural patterns socially acquired and socially transmitted by means of symbols; hence a name for distinctive achievements of human groups, including not only such items as language, tool making, industry, art, science, law, government, morals and religion, but also the material instruments or artifacts in which cultural achievements are embodied and by which intellectual cultural features are given practical effect, such as buildings, tools, machines, communication devices, art objects. In addition, Sado (2007) submits that: We must pay adequate attention to promoting our rich and diverse cultural experiences for the sake of our future. And this is a task that requires more than a negligible number of "patriotic" minds and hands in certain brackets of the media and entertainment segment of the society. Furthermore, Arowolo, (2010) describes culture as not only about dancing and music or costumes alone. It is beyond the pattern of social celebrations such as rituals pertaining to birth and marriage, cuisine or sport. Culture 
is about people's total way of life; the way we live, eat, worship, produce, create and recreate. It is the totality of a set of bequeathed ideas, belief systems, values and norms, which constitute the common bases of generally agreed social interaction (Onabajo, F. 2005).. African culture is dynamic. Culture plays a role for societal transformation and development because the stability of a society is ensured through the transmission of cultural values: (a) Community life (b) Good human relations (c) Sacredness of life (d) Hospitality (e)Mode of dressing (f) Morals (g) Respect for authority and elders; (h) Religious beliefs (i) Eating habit and food culture (j) Music (k) Marriage rites. http://www.academia.edu/5015800/African_cultural_values

\section{Cultural Imperialism Theory}

Since Herbert Schiller's book Communication and Cultural Domination first coined the phrase in 1976, the concept of cultural imperialism has often been used to refer to the idea of America exerting cultural influence over the rest of the world, with a particularly powerful imposition on Third World countries. Examples of American cultural imperialism include brand name products, mass-produced food and, perhaps of primary importance, video media. While this may come with some positive effects -- showing women's rights or racial equality in a positive light, for example -- it also tends to paint America as a leader or hero, potentially exerting a negative effect on the viewer's perception of his own country or other non American cultures.

http://classroom.synonym.com/meaning-cultural-imperialism-7841.html

Western civilization produces majority of the media (film, news, comics, etc.) because they have the money and technology to do so. The rest of the world purchases those productions because it is cheaper for them to do so rather than develop and produce their own. Third world countries are therefore watching the media filled with Western world's ways of living, beliefs and thinking. The third world cultures then start to want to do the same things western in their own poor countries. Cultural imperialism is a key feature of Marx's critique of media theory, which he viewed as dominated by the ruling classes. Via this domination, he argued, the ruling classes would best be suited to perpetuate their stranglehold on power. The ideas of the ruling classes are that in every age, the dominant material force in society, is at the same time its dominant intellectual force. The class which has the means of material production at its disposal has control at the same time over the means of mental production... in so far as they rule as a class and determine the extent and compass of each epoch, they do this in its whole range, hence, among other things, they regulate the production and distribution of the ideas of their age; thus their ideas are the ruling ideas of the epoch. Cultural imperialism is an intangible form of colonisation that was practiced by the Western empires that took over the world and exploited insidious and organic link between conquerors and the conquered.

\section{Social Learning Theory}

The theory which was formulated by Albert Bandura at Stanford University, specifies that massmedia messages give audience members an opportunity to identify with attractive characters that demonstrate behaviour, engage emotions, and allow mental rehearsal and modeling of new behaviour. The behaviour of models in the mass media also offers vicarious reinforcement to motivate audience members' adoption of the behaviour. The theory suggests that much learning takes place through observing the behaviour of others (Anaeto, Onabanjo, and Osifeso, 2008) Social learning theory argues for imitative behaviour and learning from television, such behaviours seen as rewarding and realistic. It uses both imitation and identification to explain how people learn through observation of others in their environment. What this means is that we learn through television how people from other parts of the world live their lives and even how some individuals attain greatness in their chosen careers. Television often gives such people or individuals prominence and put them in the spotlight. The tendency to act like these individuals is very high because naturally people crave to associate or identify with successful individuals. Thus, Bandura (1986) says that "people learn behaviours, emotional reactions, and attitudes from role models whom they wish to emulate.". The so-called role models are called celebrities by the media, even when such people do not necessarily possess the kind of moral righteousness expected of them. But the media promote them beyond reason and the youths want to copy them and behave like such "celebrities", who they perceive to be their heroes or heroines. This is true of majority of Nigerian youths who absorb hook, line and sinker, the Western cultural values of their heroes and imitate every aspect of their celebrities' Western ways of life: food, fashion, music and the arts, language (especially, English language slangs), rather than using the standard English language grammar or worse still their Nigerian mother tongues. Even in written 


\section{Western Television Programmes and the African Cultural Identity of Nigerian Youths}

communication the effect of the social media language can be noticed in the way most of the youth write what can be called "social media jargons" which is fast eroding the well known grammar of the English language from majority of Nigerian youths.

\section{RESEARCH METHODOLOGY}

The study adopted the survey research design method. A set of questionnaire was used to elicit information from a sample size of 274 students randomly drawn from Faculties of Afe Babalola University and Ekiti State University respectively. Frequency counts and percentages were used to analyze data. The hypothesis was tested using inferential statistical tools of Chi Square to measure data.

Table1. Respondents Desire to Live the Kind of Life Portrayed in Western TV Programmes

\begin{tabular}{|l|l|l|}
\hline \multicolumn{1}{|c|}{ OPTIONS } & FREQUENCY & PERCENTAGE \\
\hline Strongly Agree & 60 & $22 \%$ \\
\hline Agree & 64 & $23.3 \%$ \\
\hline Undecided & 56 & $20.4 \%$ \\
\hline Disagree & 51 & $18.6 \%$ \\
\hline Strongly Disagree & 43 & $15.7 \%$ \\
\hline Total & 274 & $100 \%$ \\
\hline
\end{tabular}

Table 1 shows that $22 \%$ strongly agree with the desire to live the kind of lives portrayed in western TV programmes, $23.3 \%$ agree, $20.4 \%$ are undecided, $18.6 \%$ disagree while $15.7 \%$ strongly disagree.

Table2. Regular Exposure of Youths to Western TV Programmes make Nigerian Youths Embrace Western Cultural Values and Neglect their Mother Tongues

\begin{tabular}{|l|l|l|}
\hline \multicolumn{1}{|c|}{ OREQUIONS } & PERCENTAGE \\
\hline Strongly Agree & 94 & $34.4 \%$ \\
\hline Agree & 109 & $40 \%$ \\
\hline Undecided & 22 & $8 \%$ \\
\hline Disagree & 32 & $11.6 \%$ \\
\hline Strongly Disagree & 17 & $6 \%$ \\
\hline Total & 274 & $100 \%$ \\
\hline
\end{tabular}

Table 2 shows that $34.4 \%$ strongly agree that regular exposure to western TV programmes helps Nigerian youths to embrace Western cultural values, while $40 \%$ agree, $8 \%$ are undecided, $11.6 \%$ disagree and $6 \%$ strongly disagree.

Table3. Western TV Programmes have more Negative Effects than Benefits on Nigerian Youths

\begin{tabular}{|l|l|l|}
\hline \multicolumn{1}{|c|}{ OPTIONS } & FRQUENCY & PERCENTAGE \\
\hline Strongly Agree & 78 & $28.5 \%$ \\
\hline Agree & 89 & $32.5 \%$ \\
\hline Undecided & 37 & $13.5 \%$ \\
\hline Disagree & 40 & $14.5 \%$ \\
\hline Strongly Disagree & 30 & $11 \%$ \\
\hline Total & 274 & $100 \%$ \\
\hline
\end{tabular}

Table 3 shows that $28.5 \%$ strongly agree that western TV programmes have adverse negative effects than the benefits, $32.5 \%$ agree, $13.5 \%$ are undecided while $14.5 \%$ disagree and $11 \%$ strongly disagree.

Table4. Foreign Films Should be More Censored to Reduce the Influence of Foreign Films on Nigerian Youths

\begin{tabular}{|l|l|l|}
\hline \multicolumn{1}{|c|}{ OPEIIONS } & 90 & PERCENTAGE \\
\hline Strongly Agree & 105 & $33 \%$ \\
\hline Agree & 37 & $38.3 \%$ \\
\hline Undecided & 29 & $13.5 \%$ \\
\hline Disagree & 13 & $10.5 \%$ \\
\hline Strongly Disagree & 274 & $4.7 \%$ \\
\hline Total & $100 \%$ \\
\hline
\end{tabular}

Table 4 shows that $33 \%$ strongly agree that digital satellite stations should pass through some form of censorship while $38.3 \%$ agree, $13.5 \%$ are undecided, $10.5 \%$ disagree and $4.7 \%$ strongly disagree. 
Table5. Test of Hypothesis

In testing the hypothesis, the study adopts the use of chi-square $\left(\mathrm{x}^{2}\right)$, tested at 05 level of significance.

H0 Western television programmes have no negative effect on the cultural values of Nigerian youths

\begin{tabular}{|l|l|l|l|l|}
\hline $\mathbf{O}$ & $\mathbf{E}$ & $\mathbf{O}-\mathbf{E}$ & $(\mathbf{O}-\mathbf{E})^{\mathbf{2}}$ & ${\frac{(\mathbf{O}-\mathbf{E})^{\mathbf{2}}}{\mathbf{E}}}$ \\
\hline 78 & 54.8 & 23.2 & 538.24 & 9.82 \\
\hline 89 & 54.8 & 34.2 & 1169.64 & 21.34 \\
\hline 37 & 54.8 & -17.8 & 316.84 & 5.78 \\
\hline 30 & 54.8 & -14.8 & 219.04 & 3.99 \\
\hline
\end{tabular}

Therefore chi-square is represented as

$$
\begin{aligned}
\mathrm{X}^{2}=\frac{\Sigma(\mathrm{O}-\mathrm{E})^{2}}{2} & \\
\text { Where } \mathrm{X}^{2}= & \text { Chi-square } \\
\mathrm{O}= & \text { Observed frequency } \\
\mathrm{E}= & \text { Expected frequency }
\end{aligned}
$$

H01: Western television programmes have negative effect on the cultural values of Nigerian youths. The above can be calculated thus:

$$
\begin{aligned}
\text { To get expected } & =\frac{\text { cumulative observed }}{\text { Number of attributes }} \\
& =\frac{274}{5}
\end{aligned}
$$

$$
=54.8
$$

From the analysis, $\mathrm{X}^{2}<$ table calculated, therefore the H0 is rejected. Majority of the respondents agreed that western television programmes have negative effect on the cultural values of the Nigerian youths.

\section{FINDINGS}

The study clearly showed that youths agree that Western television programmes entertain them more than the Nigerian locally produced programmes. The findings further revealed that Western television films show that there is glamorization of risky behaviours like excessive drinking and sexual promiscuity on the Western television programmes. Corroborating the above findings, Briant and Oliver (2009) states:"According to a Time/CNN poll (Stodghill, 1998), 29\% of U.S. teens identified television as their most important source of information about sex, up from 11\% in 1986". A content analysis of primetime television from the 1998-1999 season, for example, indicates that 71 percent of all programming depicted alcohol use and 77 percent contained some reference to alcohol (Christensen, Henriksen, and Roberts, 2000). A 2008 study, analyzed the link between teenage parenthood and found that teens who watched sexually explicit television (from simple shows that just talk about a character having sex to shows with soft sex scenes) were twice as likely as other teens, who had not watched much of these shows, to have a baby by age 16. The study's conclusion prompted that teens see sexually explicit content and assume that everyone is doing it so there are not any significant consequences to sex.

http://www.fuccha.in/impact-of-western-culture-on-teenagers

The study also found out that majority of Nigerian youths desire to live the kind of life that is portrayed in the Western T.V. programmes. The sad side of the exposure to foreign media on the culture of a society is that the glorification of Western lifestyle goes side by side with condemnation of the local culture. This creates a situation where Nigerians are becoming more British or America than the Americans or British themselves and this invariable, creates marginal individuals to the extent that they are neither here nor there.

http://www.datingswift.com/index.php/mass-communication/the-influence-of-western-culture-on-thenigerian-youth . 


\section{Conclusion}

From data analyzed, it is evident that there is a significant relationship between the Nigerian youths' frequent exposure to Western television programmes, and the shaping of their social behaviours. It was also noted that the influence of the programmes on the youths could be negative or positive depending on the individual and the kind of programmes to which they are exposed. Moreover, the youths admitted that the Western television programmes shown on Nigerian television screens portray Western modern lifestyles, although some of them declined that it was the ideal lifestyle which they will like to emulate. The findings of this research fall in line with the Social Learning theory which suggests that much learning takes place through observing the behaviour of others, especially through the medium of television.

Severin and Tankard (2001) were of the view that many of the effects of the mass media might take place through the process of social learning. These effects according to them might include but not limited to people learning how to wear new fashions, people getting lessons on how to interact on dates, and people assimilating behaviours that may be identified with masculinity or feminity. There is no doubt that there exists on Nigerian television screens more than needed foreign programmes with negative cultural influence. This has led to the growth of apathy towards African cultural values among the Nigerian youths in whom the traditional African cultural identity of their country lies. If the prevailing rate of weird dressing, sexual perversion, gansterism and general moral bankruptcy among the youths is anything to go by, then one can safely conclude that the country is more or less destined to wanton self-destruction, culturally.

\section{RECOMMENDATIONS}

1. This study advocates responsible journalism and television programming. This affects both the television programme developers and the broadcasters. People who drink alcohol cannot be hindered from drinking but the breweries as part of their social responsibility can emphasize in their adverts that people who drink should do it responsibly. In the same vein, young people cannot be hindered from watching Western TV programmes, because not all the programmes have negative contents, but the local TV stations as part of their social responsibility must ensure that entertainment programmes with demoralising contents are not shown at prime times. This is vital in a situation whereby the stations feel that such programmes must go on air for a certain age or social group and will not be suitable for some other age or social groups.

2. That Nigerian local TV stations can also bombard the airwaves with programmes depicting African cultural heritage. Programmes with high positive social values should be emphasized, while the negative social values should be de-emphasized. It has been noted that most of the programmes that the teenagers are exposed to, contain the negative values, while the positive values are relegated.

3. The regulatory bodies, such as the National Broadcasting Commission (NBC) and Nigerian Film Censors Board should ensure that braodcasting standards are not compromised. The NBC should henceforth enforce the policy regulating and controlling the broadcast industry; promoting Nigerian indigenous cultures, moral and communal life through broadcasting; regulating ethical standards and technical excellence in public, private and commercial broadcast stations; and applying sanctions including revocation of licenses of defaulting stations which do not operate in accordance with the broadcast code and in the public interest. Also, the Censors Board has the responsibility to sanction and ban any home videos and films that tend to portray sexual promiscuity which can easily negatively influence the youths.

\section{REFERENCES}

Salawu Abiodun., Globalisation, Multilingualism and Indigenous Language Media in Oso L. (ed.) Community Media, Voices of the Oppressed. Abeokuta: Jedidiah. 2003

Salawu A., Paradox of a Milieu: Communicating in African Indigenous Languages in the Age of Globalisation, in Salawu. A. (ed.) Indigenous Language Media in Africa. Lagos: Center for Blacks and African Arts and Civilisation. 2006

Ayedun-Alum, Victor and Tijani-Adenle, Ganiyat, Being "International": A Critique of Contemporary Philosophies and Practices of Yoruba Language Journalism in Nigeria. In Oso, L; 
Olatunji, R; and Owens-Ibie, N(eds). Journalism and Media in Nigeria. Canada University Press Concord, Ontario, Canada. 2014. Ch.6. Pp.84-100

Ariyibi-Oke,V. The advertising business in Nigeria. 2007. (Retrieved 26/11/10) from http:// www .victorariyibi.blogsspot.com/search/label/advertising.

Rodman, G. Mass media in a changing world: History, industry, controversy. New York: McGrawHill. 2006.

Babaleye, Taye., Influence of Participatory Communiation on Cereals Production in Borno State, Nigeria. Doctoral Thesis, University of Ibadan. Nigeria (2012)

Mimiko,N.O."Would Falola Frustrations Suffice?: Tradition, Governance challenges and the prospects of change in Africa in Niyi Afolabi, ed. Toyin Falola: The Man, The Mask, The

Muse. North Carolina: Carolina Academic Press. 2010

Nwaolikpe, O.N. Culture and Nigerian identity in the Print Media, Arabian Journal of Business \& Management Review (Oman Chapter) Vol.3,No 3. (2013)

Wood, J.T. Communication in our lives. Boston, Wadsworth. ( $5^{\text {th }}$ ed). (2009).

http://www.thefreedictionary.com/Western2015http://www.emeka.at/african_cultural_values

(retrieved: 10-05-2016).

Nwagbara,G. U.\& Umor, E. F. The impact of Nigerian cultural elements on the design of print media ads. Journal of Communication. (2012). www.krepublishers.com/...jc-03-2-059-12-054-TE.pdf (Retrieved 08-06-2016)

Severin,W.J. and Tankard T.W .Communication theories, Origins, Methods \& Uses in mass media( $3^{\text {rd }}$ ed.) Longman. New York. (2001)

Sado, J. Promoting indigenous culture through television and film. (2000). http://ww.Nigeriansiname rica.com/authors/308 (Retrieved: 17-11-2015), and http://www.academia.edu/5015800/ African_cultural_values ( Accessed, 07-04- 2016)

Schiller, H. J. Communication and Cultural Domination. White Plains, NY: International Arts and Sciences Press.

Arowolo, D., The effects of western civilization and culture on Nigeria Afro Asian Journal of social sciences. Vol.1, No 1, Q IV. (2010).

Onabajo, F. (2005). Promoting indigenous culture and community life in Nigeria through the mass media. Studies Tribes Tribals, 3(2): 93-98. http://www.krepublishers.com/02-

journals/T\%20\&\%20T/000-Pediatrics.aappublications.org/content/126/4/791,October2010, Volume126/issue 4.

Marx, K.\& Engels, F. Selected Works. Lawrence \&Wishart; London. 1968

Dan Ketchum, Demand Media.http://classroom.synonym.com/meaning-cultural-imperialism7841.html (retrieved 03-04-2016).

Anaeto, S. G., Onabanjo, S. O., \& Osifeso, B. J.. Models and theories of communication. Maryland: African Renaissance Books Incorporated. 2008

Bandura, A. Social foundations of thought and action.Englewood Cliffs, NJ. Prentice Hall. (1986).

Severin,W.J. and Tankard T.W. Communication theories, Origins, Methods \& Uses in mass media( $3^{\text {rd }}$ ed.) Longman. New York. 2001

Briant, J. and Oliver, M.B. Media effects: Advances in theory and research.( $3^{\text {rd }}$ ed.). Erlbaum/ Psyc hology Press. (2009)

Stodghill, R Where'd you learn that? Time, 52-59. (1998).

Christensen, P.G., Henriksen, L., Roberts, D.F. Substance use in Popular primetime television. Washington, DC: Office of National Drug Control Policy. (2000).

\section{Some Websites consulted}

http://www.fuccha.in/impact-of-western-culture-on-teenagers (retrieved: 4/6/2016)

http://www.datingswift.com/index.php/mass-communication/the-influence-of-western-culture-on-thenigerian-youth (retrieved 5/6/2016).

http://www.fuccha.in/impact-of-western-culture-on-teenagers (retrieved: 4/6/2016) 